\title{
Influence Of Environmental Properties On Macrobenthos In The North West Indian Shelf
}

\author{
K. A. JAYARAJ*, K. V. JAYALAKSHMI \& K. SARALADEVI \\ National institute of Oceanography, Regional Centre, Kochi-682018, India \\ (*Author for correspondence, e-mail: jayarajarjun@yahoo.com)
}

\begin{abstract}
The paper deals with the standing stock of macrobenthic infauna and associated environmental factors influencing the benthic community in the shelf region of the northwest Indian coast. The data were collected onboard FORV Sagar Sampada during the winter monsoon (January-February, 2003) to understand the community structure and the factors influencing the benthic distribution. The environmental parameters, sediment characteristics and macrobenthic infauna were collected at 26 stations distributed in the depths between 30 and $200 \mathrm{~m}$ extending from Mormugao to Porbander. Total benthic abundance was high in lower depths (50-75m), and low values noticed at $30 \mathrm{~m}$ depth contour was peculiar. Polychaetes were the dominant group and were more abundant in shallow and middle depths with moderate organic matter, clay and relatively high dissolved oxygen. On the other hand crustaceans and molluscs were more abundant in deeper areas having sandy sediment and low temperature. High richness and diversity of whole benthic groups observed in deeper depths counter balanced the opposite trend shown by polychaete species. Generally benthos preferred medium grain sized texture with low organic matter and high organic matter had an adverse effect especially on filter feeders. Deposit feeding polychaetes dominated in shallow depths while carnivore species in the middle depths. Ecologically, benthos were controlled by a combination of factors such as temperature, salinity, dissolved oxygen, sand and organic matter and no single factor could be considered as an ecological master factor.
\end{abstract}

Keywords: Continental shelf, Environmental parameters, Macrobenthos, Northwest Indian shelf Population density, Standing stock. 


\section{Introduction}

Nearly $40 \%$ of the total open ocean area and $30 \%$ of the total area of the world's continental shelves lie within the tropics (Alongi, 1990). Pollution, urbanization and human population growth are increasing along tropical coastlines at an alarming rate. Macrobenthos in marine sediment play an important role in ecosystem processes such as nutrient cycling, pollutant metabolism, dispersion and burial, and in secondary production (Snelgrove, 1998). Structure of benthic community is now frequently used in pollution effect monitoring programmes. Limited benthic studies have been conducted in the tropics compared to higher latitudes and the theory relating to the community structure is based largely on the studies from temperate regions (Alongi, 1990). It is important to establish baseline for tropical regions and improve our understanding of biodiversity in marine environment. The classic work of Sanders (1968) showed that within habitat marine benthic diversity for soft bottom was high in the tropics than in the boreal region. Warwick and Ruswahyuni (1987) compared the soft bottom macrobenthic community of tropical and temperate regions and suggested that abundance and biomass of tropical region is low compared to temperate region. Thorson (1957) argued that number of infaunal species of soft bottom was roughly same in arctic, temperate and tropical seas.

Studies on benthos along the shelf region of the northwestern India are limited to the studies of Neyman (1969) who studied the benthos of the shelves in the northern part of Indian Ocean. Other works in the northwest coast of India include that of Parulekar and Wagh (1975), Parulekar et al., (1976), Harkantra et al., (1980), Joydas and Damodaran (2001) and Joydas (2002). Moreover, Parulelkar et al., (1982) studied the benthos of the Indian seas. However no work has been done to elucidate the community structure of the shelf waters and the relationship between the benthos and environmental properties except that of Varshney et al., (1988) who studied the macrobenthos of very near shore depths (5-20m) off Versova, west coast of India.

\subsection{DESCRIPTION OF THE STUDY AREA}

The study area includes a part of the Indian subcontinent, which is unique in its monsoon cycle of precipitation and the accompanied dynamic changes in the hydrographical conditions of the surrounding seas, which influence its biological regime. Arabian Sea (AS) is unique among the low latitude seas because it is land locked in the north by Asian landmasses and has marked 
continental influence. It experiences seasonal reversal of atmospheric forcing, and consequently the upper layers exhibit different oceanographic characteristics during different seasons. The ecosystem is very much influenced by seasonal winds, thermohaline circulation and remote forcing. Enhanced evaporation is a peculiarity of the AS. The coastline is surrounded by the large landmasses, which enhance the differential heating. Therefore, a strong land-ocean thermal gradient develops in this region, causing monsoon. During the northeast monsoon (Nov-Feb), the winds in the coastal regions of the western India are northerly but currents flow pole ward (Darbyshire, 1967). Coastal current along the east coast of India (East India Coastal Current, EICC) flows equator wards, which carries low saline Bay of Bengal (BOB) waters, turn round Sri Lanka and continue to flow towards north as West India Coastal current (WICC) along the west coast of India. In the northern AS, cool and dry continental air brought by the prevailing northeast trade winds intensifies the evaporation leading to surface cooling. This combined with reduced incoming solar radiation and high amount of salinity drives convective mixing in the northern AS, that leads to the injection of nutrients into the surface layers from thermocline (Bhattathiri et al., 1996). The evaporative cooling and convection leads to the formation of Arabia Sea High Saline Water Masses (ASHSW) in the northern AS. The present study was under taken during the winter cooling period, which was one of the severe winters recorded recently. The paper addresses the variations in the infaunal macrobenthic community, its abundance and distribution vis-a-vis the role of environmental factors. The study covers the shelf area off Goa, Maharastra and Gujarat states located in the northwest (NW) coast of India.

\section{Materials and Methods}

Bottom water quality parameters and sediment samples were collected onboard FORV Sagar Sampada at 26 stations in the depth range of 30-200m in the continental shelf of NW coast of India during January-February 2003 (15-21 N, 69-74 E). Temperature, salinity and dissolved oxygen (hereafter referred to as DO) data were collected using a Seabird CTD and sediment samples were collected using a Smith-McIntyre grab having a mouth area of $0.1 \mathrm{~m}^{2}$ along 5 transects off Mormugao, Ratnagiri, Mumbai, Veraval and Porbander (Figure 1). The sediment sample were washed through a 0.5mm mesh sieve (Birkett and McIntyre, 1971) and then fixed and preserved using neutral formalin- Rose Bengal mixture after removing sample for texture and organic matter (hereafter referred to as OM) analysis. All organisms retained in the sieve 
were separated and the biomass was estimated (shell on) as wet weight $\left(\mathrm{g} / \mathrm{m}^{2}\right)$. Sediment samples were subjected to pipette analysis according to the standard method (Krumbein and John, 1938). The percentage composition of sand, silt and clay was calculated and plotted as triangular diagram based on the nomenclature suggested by Sheppard (1954). Organic carbon was estimated by wet oxidation method (Wakeel and Riley, 1957). Organic carbon was converted to OM (Trask, 1939) and expressed as percentage (\%) of sediment dry weight.

The data was subjected to univariate analyses for studying the benthic community structure using Margalef's richness index (Margalef, 1968) for species richness, Pielous index (Pielou, 1966) for species dominance, Shannon- Weiner index (Shannon and Weaver, 1963) for species diversity and Heips evenness index (Heip, 1974) for evenness. Karl Pearson’s correlation coefficient was used to study the affinity of the benthic groups towards environmental parameters. Multilinkage cluster analysis by group average linkage was applied for grouping the species into various clusters at different similarity levels adopting Bray Curtis similarity index (Bray and Curtis, 1957).

The data was also subjected to multivariate statistical analyses to study the influence of different environmental variables on the distribution of the benthic community using step up multiple regression model (Sokal and Rholf, 1981). The advantage of this model was that for a set of $\mathrm{k}$ input model parameters, taking into consideration all the single factor effects and the first order interaction effects, starting from $\mathrm{k}=1$, increasing by 1 and ending in $\mathrm{k}=\mathrm{k}$, this model selects the best model from among a set of $2^{\mathrm{k}}$ models. For example if $\mathrm{k}=5$ this model tests a set of 32 models and selects the best one based on the maximum variability explained by the model parameters. In addition, this model was repeated with a set of 6 types of transformations for the dependent and independent parameters ( Jayalakshmy, 1998).

\section{Results}

\subsection{WATER QUALITY PARAMETERS}

Bottom water temperature in the study area varied from $18.9^{\circ} \mathrm{C}(200 \mathrm{~m})$ to $28.3^{\circ} \mathrm{C}(75 \mathrm{~m})$ $\left(25.5 \pm 2.5^{\circ} \mathrm{C}\right.$ ). Temperature initially increased (from $30 \mathrm{~m}$ to $50 \mathrm{~m}$ or $75 \mathrm{~m}$ ) and then decreased towards deeper depths in all transects $(r=-0.833, \mathrm{p}<0.01)$ (Figure 2). In the southern transects increase was up to $75 \mathrm{~m}$ and in northern transects it was up to $50 \mathrm{~m}$ after that it decreased. At all depths, temperature decreased towards the north $(r=-0.476, p<0.05)$ (Figure 2). Salinity varied 
from 35.09 to 36.36 psu $(35.73 \pm 0.26)$ and generally increased with depth, off Mormugao, Ratnagiri and Mumbai but off Veraval it first increased slightly (at $50 \mathrm{~m}$ ) and gradually decreased towards off shore stations (Figure 3). Off Porbandar, high salinity was observed at 30 $\mathrm{m}$ and a general decrease towards deeper depths with an exceptionally high value at $120 \mathrm{~m}$ depth (Figure 3). Northward increase in salinity was obvious in $30 \mathrm{~m}$ and $50 \mathrm{~m}$ zones, and in the other zones it was fluctuating with high values at stations in the northern transect. DO values ranged from $0.16 \mathrm{ml} / \mathrm{l}$ to $4.19 \mathrm{ml} / \mathrm{l}(2.59 \pm 1.32 \mathrm{ml} / \mathrm{l})$ and showed a decrease from $30 \mathrm{~m}$ to deeper depths with a sharp decrease beyond $75 \mathrm{~m}(\mathrm{r}=-0.908, \mathrm{p}<0.01)$ (Figure 4). It increased towards north in $30 \mathrm{~m}$ to100 $\mathrm{m}$ zones and decreased towards north beyond $100 \mathrm{~m}$.

\subsection{SEDIMENT CHAR ACTERISTICS}

Six types of sediment textures were observed in the study area (Figure $5 \mathrm{a} \& \mathrm{~b}$ ) namely, sandy, clayey sand, sandy clay, silty clay, clayey silt and mixed type (more or less in equal proportion of sand, silt and clay) of sediment. Of these, silty clay, sandy and clayey sand were the major

types. Spatially, sand dominating sediment was noticed in the southern transects whereas fine sediment dominated in the northern transects (Figure $5 \mathrm{a \& b}$ ). Generally sand increased towards deeper regions, on the other hand, clay showed a reverse pattern, having high values in shallow areas and low values in deeper areas (Figure 6). Silt was usually low at almost all depth zones except at $30 \mathrm{~m}$ and $50 \mathrm{~m}$ depth zones. OM ranged from 0.18 to $4.52 \%$ (2.65 $\pm 1.17 \%)$ and varied with depth, generally high OM in shallow areas (30 m and $50 \mathrm{~m}$ ) and some exceptionally high values recorded in the deeper stations (150 m and >150 m) (Figure 7a). No latitudinal trend was observed, however, high values were observed off Ratnagiri region (Figure 7b).

\subsection{BIOMASS AND DENSITY}

Total biomass of different benthic groups together in the study area varied from $0.02 \mathrm{~g} / \mathrm{m}^{2}$ to $17.51 \mathrm{~g} / \mathrm{m}^{2}$ (Table 1). Generally, total biomass was high in shallow (50 m) and middle (75 m) depths and low in deeper depths. A noticeable feature was the low biomass production around 30m-depth in the southern transects stations. Biomass of polychaetes and miscellaneous groups were high in shallow and middle depths (up to $75 \mathrm{~m}$ ). Crustaceans were more in middle and deeper depths while molluscs were more in deeper depths. No obvious latitudinal trend was observed in the biomass of most of the groups, however excluding an exceptional high value 
observed off Ratnagiri, comparatively high biomass was observed in the northern transects. Density also showed similar pattern (Table 1). It initially increased from $30 \mathrm{~m}$ to $75 \mathrm{~m}$ then decreased with maximum average density at $75 \mathrm{~m}$ and minimum beyond $150 \mathrm{~m}$. Density of polychaete was also showing similar pattern as that of total density. Crustaceans and molluscs were more from 75 to $150 \mathrm{~m}$ depth, while miscellaneous group was low at $50 \mathrm{~m}$ and $150 \mathrm{~m}$ with more or less similar values in other depths.

\subsection{COMMUNITY STRUCTURE}

The major group polychaete contributed $80 \%$ followed by miscellaneous groups (8\%), crustacean (7\%) and molluscs (6\%) to the total fauna. Polychaetes were composed of errantia (28.3\%) and sedentaria (71.7\%). Of the 13 errant families, Pilargidae (7.8\%) and Eunicidae (6.6\%) were dominant. Among the 20-sedentarian families, Cirratulidae contributed maximum (19.7\%) to the polychaete density followed by Spionidae (15.2\%). Of the total 133-polychaete species encountered, errantia was represented by 43 species and sedentaria by 90 species. In the shallow depths deposit feeders were predominated. At $30 \mathrm{~m}$ depth Prionospio pinnata, $P$. polybranchia, Cossura coasta and Sternaspis scutata were the major species and at $50 \mathrm{~m}$ Ancistrosyllis constricta, Prionospio pinnata, Cirriformia afer were the major species (Table II). At $75 \mathrm{~m}$ depth, members of family Spionidae decreased in number and major species encountered were Cirratulis cirratus, C. chrysoderma and Amphicteis gunneri. Carnivore species like Nephtys dibranchis, Glycera longipinnis and G. alba were relatively more in number at this depth. At $100 \mathrm{~m}$ depth major species were Ancistrosyllis constricta, Cirratulis cirratus and Notomastus aberrans. Here also Nephtys and Glycera species were abundant. At $150 \mathrm{~m}$ depth, major species were Ancistrosyllis constricta, Lepidonotus carinulatus and Amphicteis gunneri while, beyond $150 \mathrm{~m}$ depth, Lepidonotus carinulatus, Syllis spongicola and Prionospio cirrobranchia were major species. Depth wise distribution showed abundance of deposit feeders in shallow depths and increased percentage of carnivores in the middle depths and representation of carnivore species in deeper depths were meager or absent. Non-polychaete taxa included crustaceans, molluscs and miscellaneous groups. Among the crustaceans, amphipods constituted more in number followed by decapods and isopods and among the molluscs gastropods were numerically abundant followed by pelecypods and in the miscellaneous group, sipunculids were the major taxa. Among amphipods Quadrivisio bengalensis was the major species and among 
gastropods, Nassarius sp. and Terebra sp. were dominant ones. In pelecypods, Mactra sp. and Tellina sp. were important species encounters in the study area in different depths.

\subsubsection{Community structure indices}

Number of polychaete species varied from 7 to 50 (22 111$)$ and abundance varied from 290 to $8825(2282 \pm 2316)$ in the southern transects. In the northern transect stations least number of species were observed and it varied between 1 to $34(19 \pm 12)$ and abundance varied from 50 to 1700 (947 \pm 614$)$. More number of species as well as higher abundance was observed in the southern transects compared to its northern counterpart. Species richness varied from 0.89 to $5.39(2.74 \pm 1.08)$ in the southern transect and 0.19 to $4.55(2.59 \pm 1.65)$ in the northern transects. Richness was more in the $75 \mathrm{~m}$ depth and low in the other depths and drastically reduced beyond $150 \mathrm{~m}$ (Fig. 8a). Evenness was more consistent in the southern transect with least value of 0.64 and highest value of $0.95(0.77 \pm 0.09)$. Since this index measures the closeness to maximum evenness, it could be stated that stations with highest evenness value, distribution was more close to the maximum uniformity. In the northern transects, this index varied between 0.28 and 0.90 (0.67 \pm 0.31$)$. High evenness was observed in the lower depths and a general decrease towards deep with highest value at $30 \mathrm{~m}$ and lowest beyond $150 \mathrm{~m}$ (Fig. 8b). Since Pielou's index varied over a large scale, the spatial variation was very high (C. V. \%=462.77\%). Species diversity showed a more consistent pattern of distribution in southern transects than northern transects. In the southern transects it ranged between 1.84 and 4.35 (3.31 0.61$)$. In the northern transects very high diversity was observed in most of the stations compared to southern transects and it varied from 0.28-4.38 (2.92 \pm 1.76$)$ with a more patchy distribution. Average diversity for the study area was 3.14 with high spatial variation $($ C.V.\% = 463.43\%). Diversity for polychaete species was generally high from $30 \mathrm{~m}$ to $100 \mathrm{~m}$ depth zones and beyond $100 \mathrm{~m}$ diversity reduced sharply with maximum diversity at $75 \mathrm{~m}$ (Fig. 8c). Pielou's index, which measures the dominance, showed that at stations with higher diversity, dominance was very low. In the southern transects dominance was low and varied between 0.08-0.37 (0.16 0.08$)$ whereas in the northern transects, it was high and varied between 0.07-1.0 (0.32 \pm 0.39$)$. In the study area as a whole, dominance was 0.2344 , which again was highly varying with space. (C. V. $=475.1 \%)$. Dominance was more or less similar up to $100 \mathrm{~m}$ and beyond that high dominance was observed (Fig. 8d). Richness based on whole benthic groups showed that in northern transects it varied from 0.7-1.61 $(1.02 \pm 0.44)$ and in southern transects it varied from $0.12-1.53(0.91 \pm 0.38)$ with more or less similar values in the northern and southern transects. Depth wise pattern was different from that 
of species with relatively more richness in the deeper depths (Fig. 8a). Evenness varied from 0.04-0.69 $(0.39 \pm 0.17)$ in southern transects and 0.27-0.81 $(0.46 \pm 0.17)$ in the northern transects. Low evenness was observed in the shallow depths and high evenness noticed beyond $75 \mathrm{~m}$ depth (Fig. 8b). Diversity in the southern transects varied from 0.04-2.27 (1.15 \pm 0.57$)$ and in the northern transects it varied from 0.71-2.26 (1.31 \pm 0.69$)$. Relatively more diversity observed in the northern transects. As that of richness and evenness, diversity was also more in the deeper depths with highest value at $150 \mathrm{~m}$ depth (Fig. 8c). Dominance in the southern transects varied form 0.31-0.99 (0.64 \pm 0.19$)$ and in northern transects it varied from 0.3-1.0 (0.61 \pm 0.22$)$. Generally no transect wise trend was observed in the group dominance. Dominance was low in 100 and $150 \mathrm{~m}$ and high in the rest of the depths (Fig. 8d).

\subsubsection{Cluster analysis}

Bray Curtis similarity index applied for grouping of stations based on polychaete density has grouped the stations into 4 clusters at $40 \%$ similarity level, calculated on $4^{\text {th }}$ root transformed density (Fig. 9a). Clustering pattern showed a definite north-south differentiations as indicated by cluster 1 which was a lone northern transect stations, cluster 2 and 3 were formed from southern transect stations, and cluster 4 was a link between southern and northern transects. Cluster 1 consisted of a deeper depth stations with high organic mater (>3\%) and low DO. The single polychaete species presenting this cluster was Cossura coasta of family Cossuridae. Cluster 2 was differentiated into fine sediment texture with high OM content, however high amount of DO $(>3 \mathrm{ml} / \mathrm{l})$ observed in these stations. All the stations in this cluster were shallow depth stations and the major families encountered were coming under family Spionidae that includes Prionospio pinnata and P. polybranchia. Cluster 3 consisted of mid and deeper depth stations with low OM and dominated by sandy sediment (>77\%). In this cluster representation of Spionidae family was meager and taken over by family Syllidae and Pilargidae. Major species were Syllis spongicola and Ancistrosyllis constricta. Amphicteis gunneri of family Ampharetidae were also found in considerable number. Cluster 4 consisted of shallow and mid-depth stations with fine sediment texture and high percentage of OM. Here deposit feeders and carnivore species were predominated. Major species were Capitella capitata, Cossura coasta, Prinospio pinnata, P. polybranchia, P. cirrifera, Magelona cincta, Notomastus aberrans, N. fauvelli, Lumbrineries hartmani, L. aberrans, Nephtys dibranchis, Glycera alba and Goniada emerita. Clusters 1 and 2 consisted of mainly deposit feeders and clusters 3 and 4 composed of mainly carnivores and deposit feeders. Similarity indices for benthic groups separated 3 clusters at 50\% 
similarity level (Fig. 9b). Unlike in the case of polychaete species, the clusters obtained were not differentiating between northern and southern transects, however, for cluster 3 , which was a lone southern region except for station \# 21 and cluster 1 which was a lone northern transect except for station \#7. Cluster 1 consisted of 4 stations and all were in the shallow depth having fine sediment texture with high DO (>3.3 ml/l). In this cluster miscellaneous group, sipunculids were noticed in high number. Nemertene worms were also observed in moderately high number. Stations also support polychaetes, decapods, amphipods in fairly high number but gastropods, scaphopods and pelecypods were meager. Stations grouped under Cluster 2 were middle depth stations (75-100m) and majority of the stations have sand or high percentage of sand. The cluster was charecterised by high abundance of pelecypods, amphipods and oligochaetes. Tanaidaceans and ophuiroides were found only in this cluster. All stations in cluster 3 were representing southern latitude stations except station 21. Stations from both shallow and deeper depths were encountered in this cluster. Shallow depth stations have fine sediment texture and deeper depth stations had coarser sediment texture. DO was high or moderately high with high percentage of OM. Scaphopods were found in high number in this cluster.

\subsection{CORRELATION OF BENTHOS WITH ENVIRONMENTAL PARAMETERS}

Polychaetes showed a significant positive correlation with temperature $(r=0.429, \mathrm{p}<0.05)$ (Table III). Positive correlation also observed with salinity, DO and sand, but not at a significant level and negatively correlated with silt, clay and OM. Crustaceans have positive correlation with salinity $(\mathrm{r}=0.421, \mathrm{p}<0.05)$ and sand $(\mathrm{r}=0.430, \mathrm{p}<0.05)$, both of which influenced significantly. Temperature, DO, silt, clay and OM were negatively correlated of which relation with silt (r=0.448, $\mathrm{p}<0.05$ ) was at significant level. Molluscs were positively correlated with temperature, salinity and sand while negatively correlated with all other environmental factors and none of them influence significantly. For miscellaneous groups, positive correlation was observed with salinity, DO, sand and negative correlation with temperature, silt, clay and OM. Total benthic abundance was positively correlated with temperature, salinity, DO and sand, while negatively correlated with silt, clay and OM. Correlation of community structure environmental variables showed that polychaete species richness was positively correlated with temperature, DO, silt and clay where as it was negatively related to salinity, sand, and OM (Table III). Evenness and diversity were positively correlated with temperature, salinity, DO, silt, and OM and negatively correlated with sand. Dominance showed a reverse trend, in which it negatively correlated with 
temperature, salinity, DO, sand, and positively correlated with silt, OM and clay. Community structure of whole benthic groups showed more or less opposite trend when compared to that of species. Since the correlation of abundance and community structure indices were feeble and most of them were not at significant level, it was inferred that there must be a group of factors influencing the benthos rather than a single factor.

To delineate the ecologically most influencing factors for the various dominant groups, we have attempted the step up multiple regression model and the mathematical equation of the best model was determined (Table IV) based on the maximum explained variability given as follows. For polychaetes, the model explained 93\% variation at $0.1 \%$ significance level $(\mathrm{p}<0.001)$. The most important factors predicting the polychaete density were silt-temperature, DO, sand, temperature-depth and temperature-DO. The most important factors predicting the variations in crustacean density were salinity, sand-salinity, sand-OM, OM, and sand. This model could explain $61 \%$ of the variability at $1 \%$ significance level $(p<0.01)$. For the density of molluscs, the model explained $83 \%$ variation at $1 \%$ significance level $(\mathrm{p}<0.01)$. The relatively more important factors were arranged as sand-silt, sand, clay, sand-clay and silt-depth. For miscellaneous groups, silt-salinity, salinity, silt, $\mathrm{OM}$ and salinity-OM were the relatively most important parameters influencing the miscellaneous group density and the model could predict the maximum variation of $51 \%$ at $1 \%$ significance level $(\mathrm{P}<0.01)$. For the total benthic density, model explains $88 \%$ variation at $1 \%$ level of significance $(\mathrm{P}<0.01)$. The most important factors were salinity-sand, sand-temperature, salinity, temperature and sand. This analysis shows that single factor effects alone could not predict a sufficient amount of the spatial variability in benthic distribution and from the results it was shown that generally three or more factors influencing the abundance and distribution of benthos. For the density of molluscs and miscellaneous groups a minimum of two environmental factors influencing significantly and for the rest of the groups more than two parameters have their influence and in any case, no single parameter alone could influence the benthos.

\section{Discussion}

Biomass and density in the present study was comparable with that of Joydas (2002) who studied the macrobenthos of the west cost of India. Biomass was relatively less than what was reported by other workers (Neyman, 1969; Harkantra et al., 1980; Parulekar et al., 1982) from the west coast and the differences noted by the other workers may be due to the differences in sampling 
strategies such as variation in gears, depth and season of sampling. It could also be related to variations in sediment properties and other environmental conditions prevailing in the area.

Benthic biomass and abundance were generally high up to $75 \mathrm{~m}$, especially that of polychaetes and decreased towards offshore (beyond $75 \mathrm{~m}$ ) thus exhibited similar pattern of distribution with temperature. DO slightly decreased from $30 \mathrm{~m}$ depth and beyond $75 \mathrm{~m}$ decrease was pronounced. The depletion of oxygen in the shelf edge of northern latitude may be associated with the oxygen minimum layer described by Gupta et al., (1976) and Qasim (1982). They have cited limited mixing, high organic production, sinking and decomposition of large amount of $\mathrm{OM}$ as the reason for the oxygen depletion. From the results it could be inferred that both temperature and DO influenced the distribution and abundance benthos. The decreased temperature in very shallow waters and moderate increase in the next higher depth is a characteristic feature of winter when the cooling of the land mass in the northern region and a general flow of cold air from the land may cause more cooling of the sea close to the land (Kumar and Prasad, 1996). The decrease in biomass and abundance in deeper depths and was in agreement with earlier reports (Neyman, 1969; Kurian, 1971; Parulekar, 1973; Parulekar and Dwivedi; 1974; Parulekar and Wagh, 1975; Ansari et al., 1977; Harkantra et al., 1980; Parulekar et al., 1982) may be due to the decrease in temperature beyond $75 \mathrm{~m}$ together with low DO. Reports by Ansari et al., (1977) mentioning the enrichment of coastal waters due to riverine flow and land run off may be one of the factors contributing to the rich fauna in the shallow region. However, Joydas and Damodaran (2001) could not find any well-defined decrease in the standing crop either with increasing depth or with distance from the coast in the west coast of India.

A general increase in salinity was found from shallow to middle depth especially in the southern transect stations. Moreover, it showed a progressive increase from south to north especially in the shallow depths (30 m and $50 \mathrm{~m}$ ). High salinity observed in the northern region in the present study might be due to the effect of Arabian Sea High Saline Water (Wyrtki, 1971) and low salinity in the southern latitudes could be due to the low saline water that enters from Bay of Bengal (BOB) through coastal waters (Darbyshire, 1967; Wyrtki, 1971; Kumar et al., 2004). Kumar and Mathew (1997) noticed that the maximum northward extension of this low saline water was up to about $12^{\circ} \mathrm{N}$ in January but could be traced upto $17^{\circ} \mathrm{N}$ in February. Exceptional high biomass noticed off Ratnagiri could be due to the impact of localized biotic and abiotic factors. Low benthic biomass at the $30 \mathrm{~m}$ contour in the southern transects could be due to reduced salinity. The higher salinity noticed in the northern transects may augment the benthic 
production in the north. High biomass observed in the shallow depths of northern transects especially at $30 \mathrm{~m}$ off Dwaraka (where high salinity observed) also confirms this point. Vizakat (1991) studied the ecology and community structure of soft sediment macrobenthos of Konkan, west coast of India, suggested recolonisation of benthos when salinity increased suggested that salinity influence positively in the benthic production in tropical waters. High benthic biomass in the shallow areas can also be due to high primary productivity in the northwest coast (Radhakrishna et al., 1978, Kumar et al., 2004) because the supply of food to the sub tidal benthic environment depends on the proximity to the shore and water depths (Levinton, 1982). In the shallow region, much of the primary production enters the food web as organic detritus. But it was also to be noted that benthos especially polychaetes were low in very high OM areas (>3\%). This may be due to their avoidance to high OM as observed by Harkantra et al., (1982).

There was a decrease in deposit feeders from shallow depths to next deeper depths and carnivore species increased. But beyond some limit (75-100m) carnivore species also decreased. Relatively high species richness, evenness and diversity were observed in depths upto75 m and decreased towards greater depths. Reason for the low richness and diversity in the deeper depths may be due to the reduced temperature, oxygen and increased depth. Latitudinaly, southern transects noticed relatively high richness and diversity while dominance was more in north. Increased richness and diveristy could be due to the increased proportion of coarser sediment in south (Long and Lewis, 1987) and also may be due to the increased temperature. Massad and Brunel (1979) and Robert (1979) also noticed increased richness with sand content which were independent of bathymetric position but, Bergen et al (2000) and Ellingsen (2002) observed that depth was the primary habitat factor organizing the southern California and Norwegian benthic community respectively followed by sediment grain size and not much effected by latitude. Ellingsen (2002) added that biotic factors such as availability and abundance of benthic larvae/adult might be more important than sediment characteristics in determinining benthic settlement. Dominance of polychaete species was high in deeper depths especially from family Spionidae, Cirratulidae and Capitellidae showed ability of these species in adverse conditions. Mirza and Gray (1981) attributed low diversity and dominance of Capitella and Polydora in the oxygen poor mud in Norway. But when considering the community structure as a whole including the polychaete showed a reverse trend that of polychaete species alone. Richness, evenness and diversity were more in deeper depths and dominance was more in shallow depths especially at $50 \mathrm{~m}$. Thus the effect of decreased richness may be counter balanced by whole benthic group giving a net effect of higher richness and diversity in the deeper depths as 
observed by Sanders (1968), Boesch (1979), Neff et al., (1989). Sanders predicted low diversity in shallow areas due to the depletion of oxygen by organic matter in the upwelling areas. But Tselepides et al., (2000) observed a decrease in diversity and abundance with depth in the continental shelf of Crete, South Aegean Sea. An opposite latitudinal trend was observed for whole community with relatively more richness and diversity in the northern transect stations

Dendrogram for polychaete and group density delineated different clusters in the southern and northern transects especially for the clusters based on polychaete density. Cluster 1of polychaete species consisted of northern transect stations differentiated to very high OM (>3\%) stations with low abundance. Presence of the single species Cossura coasta showed their ability to withstand adverse conditions of high percentage of OM and low DO. Cluster 2 was also having high OM with fine sediment texture and reduced abundance of benthos. Dominance of deposit feeding polychaetes of family Spionidae was peculiar in this cluster. Cluster 3 grouped with stations having high percentage of sand with moderate density and as the sediment texture became coarser a reduction in spionids were observed and density of family Syllidae increased. When coming to cluster 4 , which was consisted of stations from southern and northern transects of mid-depth and deeper depth stations, both deposit feeders and carnivores were getting their advantage. Thus, latitude, depth, amount of OM, sediment texture, DO and benthic abundance were the factors governing the clusters. Clusters of whole benthic groups delineated 3 clusters and cluster 1 had meager representation of gastropods, pelecypods and scaphopods, which may be due to high amount of fine sediment texture in these stations. Preference of filter feeders to coarser sediment could be clearly seen in cluster 2, which was a sand dominating cluster. The specificity of the fauna to the type of substratum largely depends on the feeding habits. Presumably fine particles of clay results in the clogging of the feeding apparatus of the filter feeders hence its avoidance of the fine particle size substrata although adequate supply of food was available (Harkantra et al., 1982). Rodrigues et al., (1982) reported that coarse sediment harbors rich fauna whereas the finer sediment was relatively impoverished and Ingole et al., (2002) noticed medium sand grain size supports more benthos. Sanders (1958; 1962) have also reported such animal-sediment relationship. Cluster 3 grouped as stations with high temperature and DO with moderately high clay which supports high density of polychaetes, decapods and amphipods. Thus different clusters were grouped mainly based on the latitude, depth, sediment texture and amount of organic matter, especially for the differentiation into northern and southern transects in which southern transects were relatively coarser sediment texture and northern transects with finer sediment texture. 
Correlation analysis nullifies influence of any particular parameter, since most of the environmental factors were not significantly correlated with benthos, suggests that a combined effects of two more factors involved in the variations in benthic community and their abundance. The most important factors were temperature, salinity, dissolved oxygen sand and depth, and no single factor could be considered as an ecological master factor (Harkantra and Parulekar, 1991).

\section{Conclusion}

Community structure of macrobenthos in the shelf waters decreases with depth and southern transects were richer in the case of polychaetes but reverse was the case with whole benthic groups. Results from the present study revealed that benthic distribution and production in the northwest coast of India were controlled by a combination of factors and effects of these factors depending on the type of organisms and major factors were temperature, salinity, dissolved oxygen, sand and depth. Low benthic production, especially polychaetes in the very shallow region (30 m) of southern transects could be due to the low temperature and salinity prevailing in that area. The decrease of benthos in deeper waters may be attributable to the low temperature and DO. Medium amount of OM with a mixture of sand and clay supports more benthic production reveals its importance as food and exceeds a limit adversely affects the organism. So, it can be deduced from the study that ecological factors like temperature, salinity and DO together with sediment characteristics have great influence on the abundance and distribution of benthic organisms and no single factor by itself has a controlling effect.

\section{Acknowledgements}

The authors are thankful to the Director, National Institute of Oceanography (NIO), Goa for the facilities provided and encouragement. Thanks are also due to the Department of Ocean Development, Govt. of India for providing on board facilities. Authors express their sincere thanks to Prof. Trevor Platt, Bedford University, Canada, Dr. C. T. Achuthankutty, Scientist-InCharge, Dr. K. K. C. Nair, Scientist-In-Charge (Rtd.), Dr. P. K. Dinesh Kumar, Mr. V. Kesavadas, Scientists, NIO, Regional Centre, Kochi, and Prof (Dr.) R. Damodaran, Cochin University of Science and Technology, Kochi for their timely valuable suggestions. The first author expresses thanks to CSIR for financial support. 


\section{References}

Alongi, D. M. (1990). The ecology of tropical soft-bottom benthic ecosystems. Oceanogr. Mar. Biol. Annu. Rev., 28, 381-496.

Ansari, Z. A., Parulekar, S.N., Harkantra, S.N. \& Ayyappan Nair. (1977). Shallow water macrobenthos of the central west coast of India. Mahasagar- Bull. Natnl. Inst. Oceanogr., 10 (3\&4), 123-127.

Bhattathiri, P. M. A., Aditi Pant, Surekha Sawant, Gauns, M., Matondkar, S. G. P., Mohanraju, R. (1996). Phytoplankton production and chlorophyll distribution in the eastern and central Arabian Sea in 1994-1995. Curr. Sci. 71(11), 857-862.

Bergen, M., Weisberg, S. B., Smith, R. W., Cadien, D. B., Dalkey, A., Montagne, D. E., Ranasinghe, J. A. (2000). Relationship between depth, sediment, latitude, and the structure of benthic infaunal assemblages on the mainland shelf of southern California. Mar. Bio. 138 (3), 637-647.

Birkett, L. \& McIntyre, A. D.(1971). Treatment and sorting of samples. In: Methods for the study of marine benthos, IBP Handbook No. 16: Blackwell Sci. Publ. Oxford and Edinburgh,157 p.

Boesch, D. F. (1979). Benthic ecological studies: macrobenthos. In vol IIB. Chemical and biological benchmark studies. Virginia Institute of Marine Science Report to US Depertment of the Interior Bureau of Land Management. Gloucester Point, Va. Contact No. AA 550-CT 6-62. VIMS Special Report in Appl Mar. Sci Ocean Eng No. 194, 1-301.

Bray, J. R.\& Curtis, J. J. (1957). An ordination of the upland forest communities of southern Wisconsin. Ecol. Monogr., 27, 325-349.

Darbyshire, M.(1967). The surface waters off the coast of Kerala. Deep Sea Res., 14, 295-320.

Ellingsen K. E. (2002). Soft-sediment benthic biodiversity on the continental shelf in relation to environmental variability. Mar. Ecol. Prog. Ser., 232,15-27.

Gupa, Sen R., Rajagopal, M. D., Qasim, S. Z., 1976. Relationships between dissolved oxygen and nutrients in the north-westtern Indian Ocean. Indian J. Mar. Sci. 5, 201-211.

Harkantra, S. N., Ayyappan Nair, Ansari, Z. A. \& Parulekar, A. H. (1980). Benthos of shelf region along the west coast of India. Indian J. mar. Sci., 9, 106-110.

Harkantra, S. N., Rodrigues, C. L. \& Parulekar, A H. (1982). Macrobenthos off the shelf of North Eastern Bay of Bengal. Indian J. mar. Sci., 11, 115-121.

Harkantra, S. N. \& Parulekar, A. H. (1991). Interdependence of environmental parameters and sand dwelling benthic species abundance: a multivariate approach. Indian J. Mar. Sci., 20, 232234.

Heip, C. (1974). A new index measuring evenness. Mar. Bilo. Ass. (U.K), 54, 555-557. 
Ingole, B., Rodrigues, N. \& Ansari, Z. A. ( 2002). Macrobenthic communities of the Coastal waters of Dabhol, westcoast of India. Indian J. mar. Sci., 31(2), 93-99.

Jayalakshmi, K. V. 1998. Biometric studies on the trophic level relation in the Indian Ocean. Ph. D. Thesis, Cochin University of Science and Technology.

Joydas, T. V. \& Damodaran, R. (2001, October). Macrobenthic polychaetes along the shelf waters of the west coast of India. (Paper presented at IAPSO/IABO Ocean Odyssey Conference held at Mar Del Plata).

Joydas, T. V. (2002). Macrobenthos of the shelf waters of the west coast of India. Ph. D thesis submitted to Cochin University of Science and Technology.

Krumbein \& Petti John F. J. (1938). Manual of Sedimentary Petrography Appleton Century Crafts. New York, 549 p.

Kumar Hareesh, P. V. \& Mathew Basil (1997). Salinity distribution in the Arabian Sea. Indian J. mar. Sci., 26, 271-277.

Kumar, Prasanna S. \& Prasad, T. G. (1996). Winter cooling in the northern Arabian Sea. Current Science, 71(11), 834-841.

Kumar, Prasanna S., Narvekar, J., Kumar, A., Shaji, C., Anand, P., Sabu, P., Rijomon, G., Josia, J., Jayaraj, K. A., Radhika, R. \& Nair, K. K. C. (2004). Intrusion of the Bay of Bengal water into the Arabian Sea during winter monsoon and associated chemical and biological response. Geophysical Research Letters, 31,L 15304, doi: 10.1029/2004 GL020247, 2004.

Kurian, C.V. (1971). Distribution of benthos on the southwest coast of India. ( In: Fertility of the sea, J.D. Costlow (Jr) (Eds.) (Gordon and Breach Scientific Publication, (pp. 225-239) .New York.)

Levinton, J. S. (1982). Marine Ecology. (Prentice-Hall Inc., New Jersey, pp. 526)

Long, B. \& Lewis, J. B. (1987). Distributioon and community structure of the benthic fauna of the north shore of the Gulf of St. Lawrence described by numerical methods of classification and ordination. Mar. Biol. 95, 93-101.

Margalef, R., (1968). Perspectives in ecological theory. (Univ. Chicago Press)

Massad, R. \& Brunel, P. (1979). Associations par stations, densites et diversite des polychates du benthos circalittoral et bathyal de estuaire maritime du Saint Laurent. Nat. can., 106,229-253.

Mirza, F. B. and Gray, J. S. (1981). The fauna of benthic sediments from the organically enriched Oslofjord, Norway. J. exp. Mar. Biol. Ecol., 54,181-207. 
Neff, J. M., Bothner, M. H., Maciolek, N. J., Grassle, J. F. (1989). Impact of exploratory drilling for oil and gas on the benthic environment of Georges Bank. Mar. Environ. Res., 27,77-114

Neyman A. A. (1969). Some data on the benthos of the shelves in the northern part of the Indian Ocean. (Paper presented at the scientific conference on the tropical zone of the oceans, All Union Scientific Research Institute of Marine Fisheries and Oceanography, U.S.S.R.)

Parulekar, A. H. \& Dwivedi, S. N. (1974). Benthic studies in Mormugao estuaries, Part-I Standing crop and faunal composition in relation to bottom salinity distribution and substratum characteristics in the estuary of Mandovi River. Indian J. mar. Sci., 3, 41-45.

Parulekar, A. H. (1973). Quantitative distribution of Benthic fauna on the inner shelf of central west coast of India. Indian J. mar. Sci., 2, 113-115.

Parulekar, A. H., Nair, S. A., Harkantra, S. N. \& Ansari, Z. A. (1976). Some quantitative studies on the benthos off Bombay. Mahasagar, 9(1\&2), 51-56.

Parulekar, A.H., Harkantra, S. N. \& Anzari, Z. A. (1982). Benthic production and assessment of demersal fishery resources of the Indian seas. Indian J. mar. Sci., 11, 107-114.

Parulekar, A. H \& Wagh, A. B. (1975). Quantitative studies on benthic macrofauna of northeastern Arabian Sea shelf. Indian J. mar. Sci., 4, 174-176.

Pielou, E. C. (1966). Species diversity and patern diversity in the study of ecological succession. J. Theor. Biol., 10, 372-383.

Qasim, S. Z. (1982). Oceanography of the northern Arabian Sea. Deep Sea Res., 29,1041-1068.

Radhakrishna, K., Devassy, V. P., Bhattathiri, P. M. A. \& Bhargava, R. M. S. (1978). Primary productivity in the northeastern Arabian Sea. Indian J. mar. Sci., 7,137-139.

Robert, G. (1979). Benthic molluscan faunaof the St. Lawrence estuaty and ecology as assessed by numerical methods. Nat. can., 106, 211-227.

Rodrigues, C. L., Harkantra, S. N. \& Parulekar, A. H. (1982). Sub-littoral meiobenthos of the northeastern Bay of Bengal. Indian J. Mar. Sci., 11, 239-242.

Sanders, H. L., Goudsmith, E. L., Mills, E. L. \& Hampson, G. E. (1962).Limn. Oceanogr, 7,79 p.

Sanders, H. L. (1958). Benthic Studies in Buzzards Bay, I. Animal sediment Relationships, Limnol. Oceanogr, 3,245-258.

Sanders, H. L. (1968). Marine Benthic diversity: A comparative study. Am. Nat. 102 (925), 243282.

Shannon, C. E., Weaver, W. (1963). The mathematical theory of communication. University of Illinois Press, Urbana, Illinois. 
Shepard, F. P. (1954). Nomenclature based on the sand-silt-clay ratios. J. Sed. Petrol., 24,151158.

Sokal, R. R. \& Rholf, J. F. (1981). In: Biometry , The Principles and Practise of Statistics in Biological research. ( $2^{\text {nd }}$ Edn, W. H. Freeman and Company, New York)

Snelgrove, P.V.R. (1998). The biodiversity of macrofaunal organisms in marine sediments. Biodiv. Conserv., 7, 1123-1132.

Thorson, G. (1957). Bottom communities (sublottoral or shallow shelf). (In: Treatise on Marine Ecology and Paleoecology, Vol I, Ecology, J. W. Hedgpeth (Ed), Geol. Soc. Am. Mem. 67, 461535.

Trask, P. D. (1939). In: Recent marine sediments. Amn. Assoc. of Petroleum. Geologists Publ. Tulsa, Oklohama, USA., 736 p.

Tselepides, A. Papadopoulou, K. N. Podaras, D. Plaiti, W \& Koutsoubas, D. (2000). Macrobenthic community structure over the continental margin of Crete (South Aegean Sea, NE Mediterranean). Prog. Oceanogr. , 46, 401-428

Varshney, P. K. , Govindan, K., Gaikwas U. D. \& Desai, B. N. (1988). Macrobenthos off Versova (Bombay), west coast of India, in relation to environmental conditions. Indian, J. Mar. Sci. 17, 222-227.

Vizakat Lathika, Harkantra, S. N., Parulekar, A. H. (1991). Population ecology and community structure of subtidal soft sediment dwelling macro-invertebrates of Konkan, West coast of India. Indian J. Mar. Sci., 20 (1), 40-42.

Wakeel, EL S. K. \& Riley, J. P. (1957). Determination of organic carbon in marine mud. J. Cons. Perm. Int. Explor. Mer., 22, 180-183.

Warwick, R. M. \& Ruswahyuni (1987). Comparative study of the structure of some tropical and temporate marine soft-bottom macrobenthic communities. Mar. Biol., 95, 641-649.

Wyrtki, K. (1971). Oceanographic atlas of the International Indian Ocean Expedition, National Science Foundation, U.S. Government of Printing Office, Washington D.C., 531 p. 


\section{Legend to Figures}

Figure 1. Station location

Figure 2. Depth wise distribution of temperature in various transects

Figure 3. Depth wise distribution of salinity in various transects

Figure 4. Depth wise distribution of dissolved oxygen in various transects

Figure 5. Sediment texture in the study area a) southern transects, b) northern transects

Figure 6. Depth wise distribution of sediment texture in the study area

Figure 7. Distribution of Organic matter

a) Depth wise

b) Transect wise

Figure 8. Depthwise (average) distribution of community structure indices

a) Richness b) Evenness c) Diversity d) Dominance

Figure 9. Dendrogram (MDS) for stations

a) Based on polychaete density b) Bades on whole benthic group density 
TABLE I

Biomass and density (in brackets) distribution in the study area

\begin{tabular}{|c|c|c|c|c|c|}
\hline Transects & Polychaetes & Crustaceans & Molluscs & Others & $\begin{array}{r}\text { Total } \\
\text { biomass }\end{array}$ \\
\hline \multicolumn{6}{|l|}{ Off Marmagoa } \\
\hline 30 & $0.26(830)$ & $0.01(10)$ & $0.12(30)$ & $0.65(130)$ & $1.04(1000)$ \\
\hline 50 & $8.80(5230)$ & $0.00(0)$ & $0.00(0)$ & $0.17(20)$ & $8.98(5220)$ \\
\hline 75 & $0.83(840)$ & $0.02(30)$ & $1.58(160)$ & $0.17(20)$ & $2.60(1050)$ \\
\hline 100 & $0.20(1860)$ & $0.03(20)$ & $0.46(180)$ & $0.17(20)$ & $0.87(2080)$ \\
\hline Average & 2.52(2190) & $0.02(15)$ & $0.54(93)$ & $0.29(48)$ & 3.37(2345) \\
\hline SD & $4.20(2083)$ & $0.01(13)$ & $0.72(91)$ & $0.24(55)$ & $3.82(2000)$ \\
\hline \multicolumn{6}{|l|}{ Off Ratnagiri } \\
\hline 30 & $0.41(260)$ & $0.02(10)$ & $0.42(290)$ & $0.01(10)$ & $0.86(570)$ \\
\hline 50 & $0.96(490)$ & $0.08(70)$ & $0.49(110)$ & $0.03(40)$ & $1.56(710)$ \\
\hline 75 & $14.73(8750)$ & $0.54(490)$ & $0.39(450)$ & $1.85(400)$ & $17.51(10090)$ \\
\hline 100 & 1.77(1450) & $0.03(30)$ & $0.10(330)$ & $0.14(120)$ & 2.04(1930) \\
\hline Average & $4.47(2738)$ & $0.17(150)$ & $0.35(295)$ & $0.51(143)$ & $5.49(3325)$ \\
\hline SD & $6.86(4041)$ & $0.25(228)$ & $0.17(141)$ & $0.89(178)$ & $8.03(4551)$ \\
\hline \multicolumn{6}{|l|}{ Off Mumbai } \\
\hline 30 & $1.61(1400)$ & $0.01(20)$ & $0.69(170)$ & $0.04(10)$ & $2.35(1600)$ \\
\hline 50 & $14.00(2950)$ & $0.10(260)$ & $0.09(60)$ & $1.68(50)$ & $15.87(3320)$ \\
\hline 75 & $2.83(3440)$ & $0.08(130)$ & $0.46(140)$ & $0.03(80)$ & $3.40(3790)$ \\
\hline 100 & $0.25(1030)$ & $0.24(580)$ & $0.38(160)$ & $0.34(360)$ & $1.21(2130)$ \\
\hline 150 & $0.82(1190)$ & $2.90(365)$ & $0.27(50)$ & $1.87(280)$ & 5.86(1885) \\
\hline 200 & $0.06(700)$ & $0.34(110)$ & $0.00(0)$ & $0.21(420)$ & $0.61(1230)$ \\
\hline Average & $3.26(1867)$ & $0.61(287)$ & $0.31(105)$ & $0.70(177)$ & $4.88(2435)$ \\
\hline SD & 5.36(1092) & $1.13(255)$ & $0.25(67)$ & $0.85(172)$ & $5.69(987)$ \\
\hline \multicolumn{6}{|l|}{ Off Veraval } \\
\hline 30 & $1.29(970)$ & $0.01(70)$ & $0.00(0)$ & $3.62(150)$ & 4.92(1190) \\
\hline 50 & 2.68(1070) & $0.01(10)$ & $0.00(0)$ & $0.76(130)$ & $3.45(1210)$ \\
\hline 75 & $0.77(430)$ & $1.00(50)$ & $0.00(0)$ & $2.25(50)$ & $4.02(530)$ \\
\hline 100 & $0.26(1610)$ & $0.05(180)$ & $1.88(170)$ & $0.09(260)$ & $2.28(2400)$ \\
\hline 150 & $0.00(10)$ & $0.03(30)$ & $1.72(50)$ & $0.01(30)$ & $1.76(140)$ \\
\hline 200 & $0.02(10)$ & $0.00(0)$ & $0.00(0)$ & $0.00(0)$ & $0.02(10)$ \\
\hline Average & $0.84(683)$ & $0.18(57)$ & $0.60(70)$ & $1.12(103)$ & 2.74(913) \\
\hline SD & $1.03(642)$ & $0.40(66)$ & $0.93(140)$ & $1.50(96)$ & $1.76(887)$ \\
\hline \multicolumn{6}{|l|}{ Off Dwaraka } \\
\hline 30 & $5.18(1380)$ & $0.05(110)$ & $0.15(30)$ & $8.87(220)$ & $14.25(1740)$ \\
\hline 75 & $5.03(1160)$ & $0.26(330)$ & $0.14(70)$ & $1.29(870)$ & $6.72(2430)$ \\
\hline 100 & $3.58(1220)$ & $0.04(190)$ & $0.24(170)$ & $0.09(180)$ & $3.95(1760)$ \\
\hline 150 & $1.51(1550)$ & $0.67(170)$ & $0.23(50)$ & $0.26(30)$ & $2.67(1800)$ \\
\hline Average & 3.83(1328) & $0.26(200)$ & $0.19(80)$ & $2.63(325)$ & 6.90(1933) \\
\hline SD & $1.70(175)$ & $0.29(93)$ & $0.05(62)$ & $4.20(372)$ & $5.19(333)$ \\
\hline
\end{tabular}


Table II

Depth wise distribution of polychaetes species (included only species contributing $>5 \%$ to density in a particular depth)

\begin{tabular}{llrrrrrr}
\hline \multicolumn{1}{c}{ Species } & \multicolumn{1}{c}{ Family } & $\mathbf{3 0 m}$ & $\mathbf{5 0 m}$ & $\mathbf{7 5 m}$ & $\mathbf{1 0 0 m}$ & $\mathbf{1 5 0 m}$ & $\mathbf{2 0 0 m}$ \\
\hline $\begin{array}{l}\text { Lepidonotus } \\
\text { carinulatus }\end{array}$ & Aphroditidae & & & & & & \\
Ancistrosyllis & Pilargidae & 0.00 & 0.00 & 0.07 & 1.26 & 9.88 & 40.85 \\
constricta & & & & & & \\
Syllis spongicola & Syllidae & 5.79 & 9.45 & 5.20 & 9.21 & 12.04 & 5.63 \\
Lumbrineries & Eunicidae & & & & & & \\
hartmani & & 1.65 & 1.03 & 0.89 & 0.42 & 5.25 & 0.00 \\
Eunice indica & Eunicidae & 0.00 & 0.00 & 0.00 & 0.00 & 7.41 & 0.00 \\
Dorvillea gardineri & Eunicidae & 0.00 & 1.23 & 5.40 & 0.70 & 0.00 & 0.00 \\
Prionospio pinnata & Spionidae & 12.40 & 8.42 & 3.15 & 7.81 & 2.78 & 0.00 \\
P.polybranchia & Spionidae & 10.95 & 1.95 & 7.80 & 1.39 & 2.47 & 0.00 \\
P. cirrobranchia & Spionidae & 1.65 & 0.51 & 3.56 & 2.37 & 0.00 & 7.04 \\
Cirratulis cirratus & Cirratulidae & 1.45 & 4.00 & 11.70 & 11.16 & 2.47 & 2.82 \\
C.chrysoderma & Cirratulidae & 0.00 & 0.10 & 8.76 & 0.00 & 0.00 & 0.00 \\
Cauleriella capensis & Cirratulidae & 0.00 & 7.60 & 0.00 & 0.00 & 0.00 & 0.00 \\
Cirriformia afer & Cirratulidae & 1.45 & 18.58 & 3.35 & 0.84 & 0.62 & 0.00 \\
Ophelina sp. & Opheliidae & 0.00 & 5.34 & 0.00 & 0.00 & 0.00 & 0.00 \\
Cossura coasta & Cossuridae & 15.08 & 6.37 & 1.44 & 6.69 & 1.23 & 1.41 \\
Notomastus aberrans & Capitellidae & 1.03 & 0.41 & 0.55 & 15.48 & 2.78 & 0.00 \\
Sternaspis scutata & Strenaspidae & 10.12 & 2.87 & 0.21 & 0.14 & 0.00 & 0.00 \\
Amphicteis gunneri & Ampharetidae & 1.24 & 5.03 & 12.24 & 5.02 & 15.12 & 2.82 \\
Nephtys dibranchis & Nephtydae & 1.45 & 1.64 & 3.83 & 2.00 & 0.93 & 0.00 \\
\hline
\end{tabular}


Table III

Correlation of benthic groups with environmental parameters

\begin{tabular}{lrrrrrrr}
\hline & Temperature & \multicolumn{1}{c}{ Salinity } & \multicolumn{1}{c}{ DO $^{\dagger}$} & \multicolumn{1}{c}{ Sand } & \multicolumn{1}{l}{ Silt } & \multicolumn{1}{c}{ Clay } & OM $^{\ddagger}$ \\
\hline Polychaetes & $0.429 *$ & 0.126 & 0.17 & 0.179 & -0.256 & -0.048 & -0.215 \\
Crustaceans & -0.066 & $0.421^{*}$ & -0.18 & $0.430^{*}$ & $-0.448^{*}$ & -0.299 & -0.385 \\
Molluscs & 0.331 & 0.119 & -0.042 & 0.305 & -0.248 & -0.283 & -0.033 \\
Others & -0.098 & 0.314 & 0.044 & 0.164 & -0.122 & -0.167 & -0.387 \\
Total & 0.397 & 0.189 & 0.141 & 0.236 & -0.3 & -0.103 & -0.27 \\
& & & \multicolumn{7}{c}{ Polychaete species } & & \\
\hline Richness & 0.2784 & -0.277 & 0.2507 & -0.0729 & 0.0521 & 0.0764 & -0.4619 \\
Diversity & 0.3199 & 0.2078 & 0.2436 & -0.035 & 0.0368 & 0.0248 & -0.4483 \\
Evenness & 0.2945 & 0.0046 & 0.1692 & -0.0035 & 0.0019 & -0.0134 & -0.2578 \\
Dominance & -0.395 & -0.0983 & -0.2478 & -0.0188 & 0.019 & 0.0114 & 0.4032 \\
& & & Whole benthic groups & & \\
\hline Richness & -0.1056 & 0.6811 & -0.0157 & 0.1975 & -0.1404 & -0.2007 & -0.4251 \\
Diversity & -0.1842 & 0.3129 & -0.1646 & 0.1625 & -0.0568 & -0.2289 & -0.1285 \\
Evenness & -0.0969 & 0.0804 & -0.0951 & 0.0421 & 0.0618 & -0.1425 & 0.0786 \\
Dominance & 0.1677 & -0.1908 & 0.1572 & -0.1351 & 0.0175 & 0.2231 & 0.0452 \\
\hline
\end{tabular}

$\mathrm{N}=24$

*Correlated at 5\%significance level

$\dagger$ - Dissolved oxygen

‡- Organic matter 
Table IV. Multiple regression model for benthic groups

\begin{tabular}{|c|c|c|c|c|}
\hline $\begin{array}{l}\text { Variabl } \\
\text { es }\end{array}$ & Best model & F ratio & $\begin{array}{l}\text { Variability } \\
\text { explained }\end{array}$ & $\begin{array}{l}\text { Model input } \\
\text { variables }\end{array}$ \\
\hline $\begin{array}{l}\text { Polycha } \\
\text { etes }\end{array}$ & 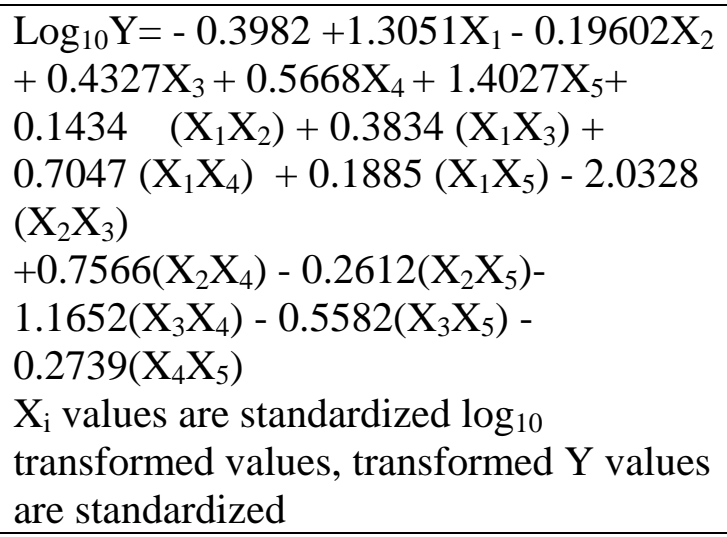 & $\begin{array}{l}\mathrm{F}_{(15,8)} \\
=22.0979 \\
\mathrm{P}<0.001\end{array}$ & $93.23 \%$ & $\begin{array}{l}\mathrm{X}_{1} \text { - sand } \\
\mathrm{X}_{2} \text {-silt } \\
\mathrm{X}_{3} \text {-temperature } \\
\mathrm{X}_{4} \text {-depth }\end{array}$ \\
\hline $\begin{array}{l}\text { Crustac } \\
\text { eans }\end{array}$ & $\begin{array}{l}\log _{10} \mathrm{Y}=-0.2015-0.01638 \mathrm{X}_{1}+ \\
1.0380 \mathrm{X}_{2}-0.1552 \mathrm{X}_{3}+0.5283\left(\mathrm{X}_{1} \mathrm{X}_{2}\right)- \\
0.2819 \\
\quad\left(\mathrm{X}_{1} \mathrm{X}_{3}\right)+0.1186\left(\mathrm{X}_{2} \mathrm{X}_{3}\right) \\
\mathrm{X}_{\mathrm{i}} \text { values are standardized } \log _{10} \\
\text { transformed values, transformed } \mathrm{Y} \text { values } \\
\text { are standardized }\end{array}$ & $\begin{array}{l}\mathrm{F}_{(6,17)} \\
=7.0252 \\
\mathrm{P}<0.01\end{array}$ & $61.21 \%$ & $\begin{array}{l}\mathrm{X}_{1} \text { - sand } \\
\mathrm{X}_{2} \text {-salinity } \\
\mathrm{X}_{3} \text {-OM }\end{array}$ \\
\hline $\begin{array}{l}\text { Mollusc } \\
\text { s }\end{array}$ & $\begin{array}{l}\mathrm{Y}=-1.0470+2.3277 \mathrm{X}_{1}+1.8504 \mathrm{X}_{2}+ \\
1.4935 \mathrm{X}_{3}-0.0654 \mathrm{X}_{4}+1.2503 \mathrm{X}_{5}+ \\
0.7746 \mathrm{X}_{6} \\
\quad-1.9038\left(\mathrm{X}_{1} \mathrm{X}_{2}\right)-3.8259\left(\mathrm{X}_{1} \mathrm{X}_{3}\right)- \\
1.0162\left(\mathrm{X}_{1} \mathrm{X}_{4}\right)+0.8868\left(\mathrm{X}_{1} \mathrm{X}_{5}\right)- \\
0.2679\left(\mathrm{X}_{1} \mathrm{X}_{6}\right)-0.3695 \\
\quad\left(\mathrm{X}_{2} \mathrm{X}_{3}\right)-1.9036\left(\mathrm{X}_{2} \mathrm{X}_{4}\right)-0.1604\left(\mathrm{X}_{2} \mathrm{X}_{5}\right) \\
+0.3007\left(\mathrm{X}_{2} \mathrm{X}_{6}\right)-1.7648\left(\mathrm{X}_{3} \mathrm{X}_{4}\right)+ \\
0.4314\left(\mathrm{X}_{3} \mathrm{X}_{5}\right) \\
\quad-2.7214\left(\mathrm{X}_{3} \mathrm{X}_{6}\right)+0.3116\left(\mathrm{X}_{4} \mathrm{X}_{5}\right)+ \\
0.2324\left(\mathrm{X}_{4} \mathrm{X}_{6}\right)+0.3348\left(\mathrm{X}_{5} \mathrm{X}_{6}\right) \\
\mathrm{X}_{\mathrm{i}} \text { values are standardized } \log _{10} \\
\text { transformed values, } \mathrm{Y} \text { values are } \\
\text { standardized }\end{array}$ & $\begin{array}{l}\mathrm{F}_{(21,2)} \\
=6.5149 \\
\mathrm{P}<0.01\end{array}$ & $83.43 \%$ & $\begin{array}{l}\mathrm{X}_{1} \text {-sand } \\
\mathrm{X}_{2} \text {-clay } \\
\mathrm{X}_{3} \text {-silt } \\
\mathrm{X}_{4} \text {-temperature } \\
\mathrm{X}_{5} \text {-salinity } \\
\mathrm{X}_{6} \text {-depth }\end{array}$ \\
\hline $\begin{array}{l}\text { Miscell } \\
\text { aneous } \\
\text { groups }\end{array}$ & $\begin{array}{l}\mathrm{Y}=-0.1815+0.7578 \mathrm{X}_{1}+1.0443 \mathrm{X}_{2}- \\
0.6648 \mathrm{X}_{3}-1.3757\left(\mathrm{X}_{1} \mathrm{X}_{2}\right)+0.0807 \\
\left(\mathrm{X}_{1} \mathrm{X}_{3}\right) \\
\quad+0.4183\left(\mathrm{X}_{2} \mathrm{X}_{3}\right) \\
\mathrm{X}_{\mathrm{i}} \text { values are standardized } \log _{10} \\
\text { transformed values, } \mathrm{Y} \text { values are } \\
\text { standardized }\end{array}$ & $\begin{array}{l}F_{(6,17)} \\
=5.0640 \\
P<0.01\end{array}$ & $51.46 \%$ & $\begin{array}{l}X_{1} \text { - silt } \\
X_{2} \text { - salinity } \\
X_{3}-O M\end{array}$ \\
\hline $\begin{array}{l}\text { Total } \\
\text { density }\end{array}$ & $\begin{array}{l}\mathrm{Y}=0.38093+0.1661 \mathrm{x}_{1}-0.21821 \mathrm{x}_{2^{-}} \\
0.4665 \mathrm{x}_{3}+0.14019 \mathrm{x}_{4}+0.7749\left(\mathrm{x}_{1} \mathrm{x}_{2}\right)+1.220 \\
4\left(\mathrm{x}_{1} \mathrm{x}_{3}\right)-0.15848\left(\mathrm{x}_{1} \mathrm{x}_{4}\right)+0.06368\left(\mathrm{x}_{2} \mathrm{x}_{3}\right) \\
+0.1394\left(\mathrm{x}_{2} \mathrm{x}_{4}\right)-0.17953\left(\mathrm{x}_{3} \mathrm{x}_{4}\right)\end{array}$ & $\begin{array}{l}\mathrm{F}_{(10,13)} \\
=17.141 \\
\mathrm{P}<0.01\end{array}$ & $87.53 \%$ & $\begin{array}{l}\mathrm{X}_{1} \text { - sand } \\
\mathrm{X}_{2} \text {-temperature } \\
\mathrm{X}_{3} \text { - salinity } \\
\mathrm{X}_{4} \text {-depth }\end{array}$ \\
\hline
\end{tabular}




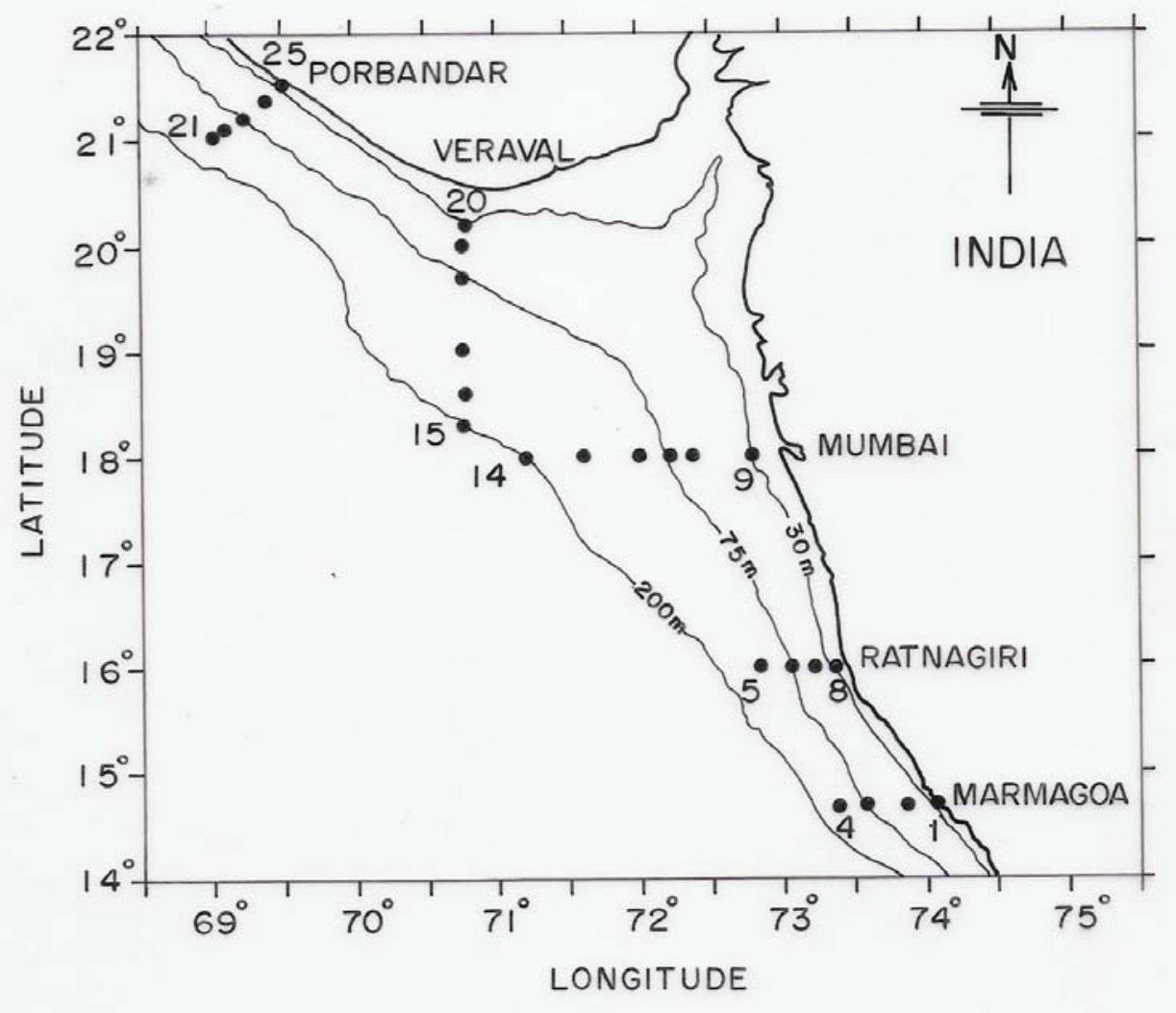

Figure 1. 


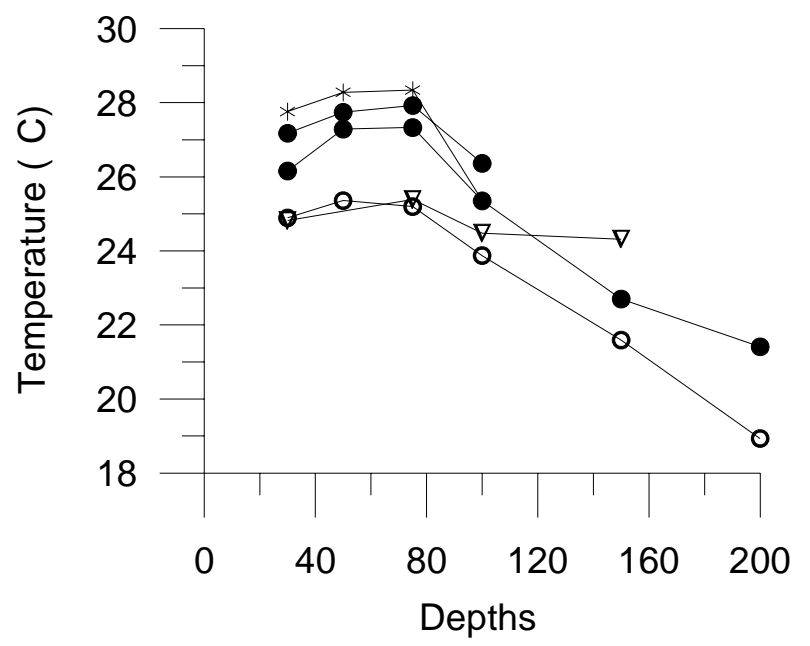

Figure 2.

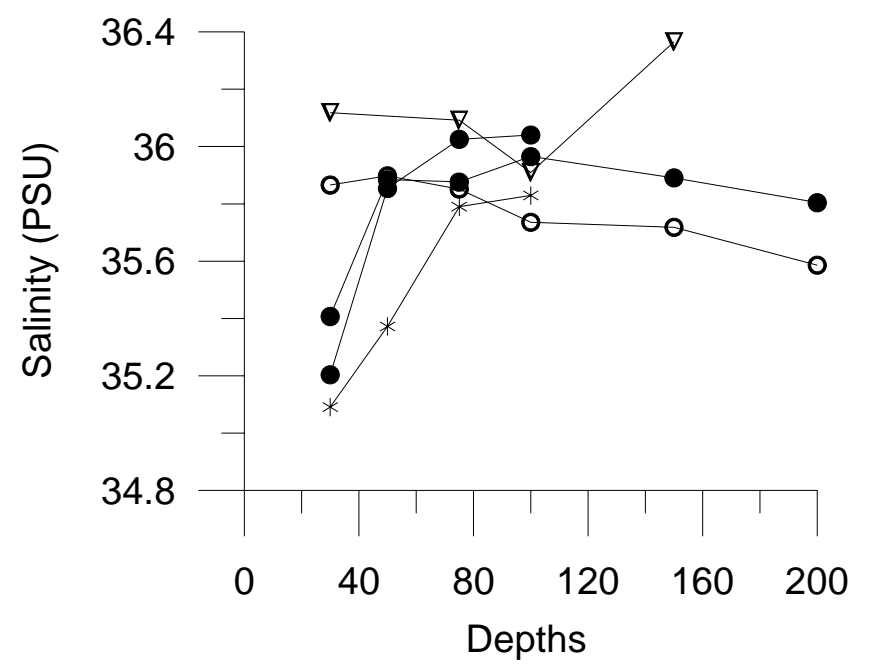

Figure 3.

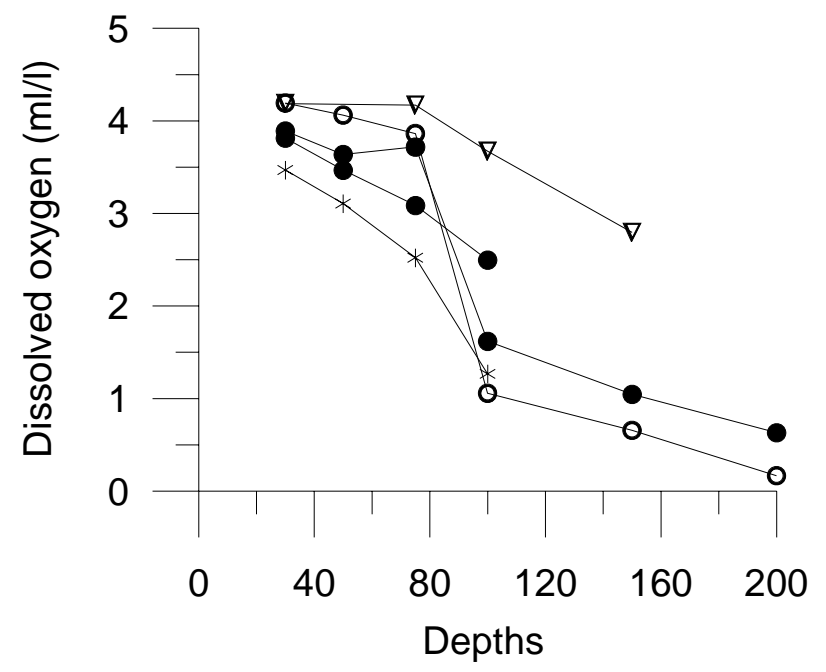

Figure 4.

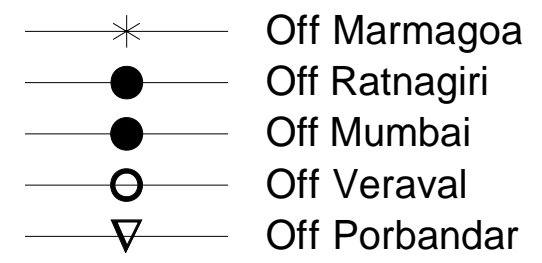




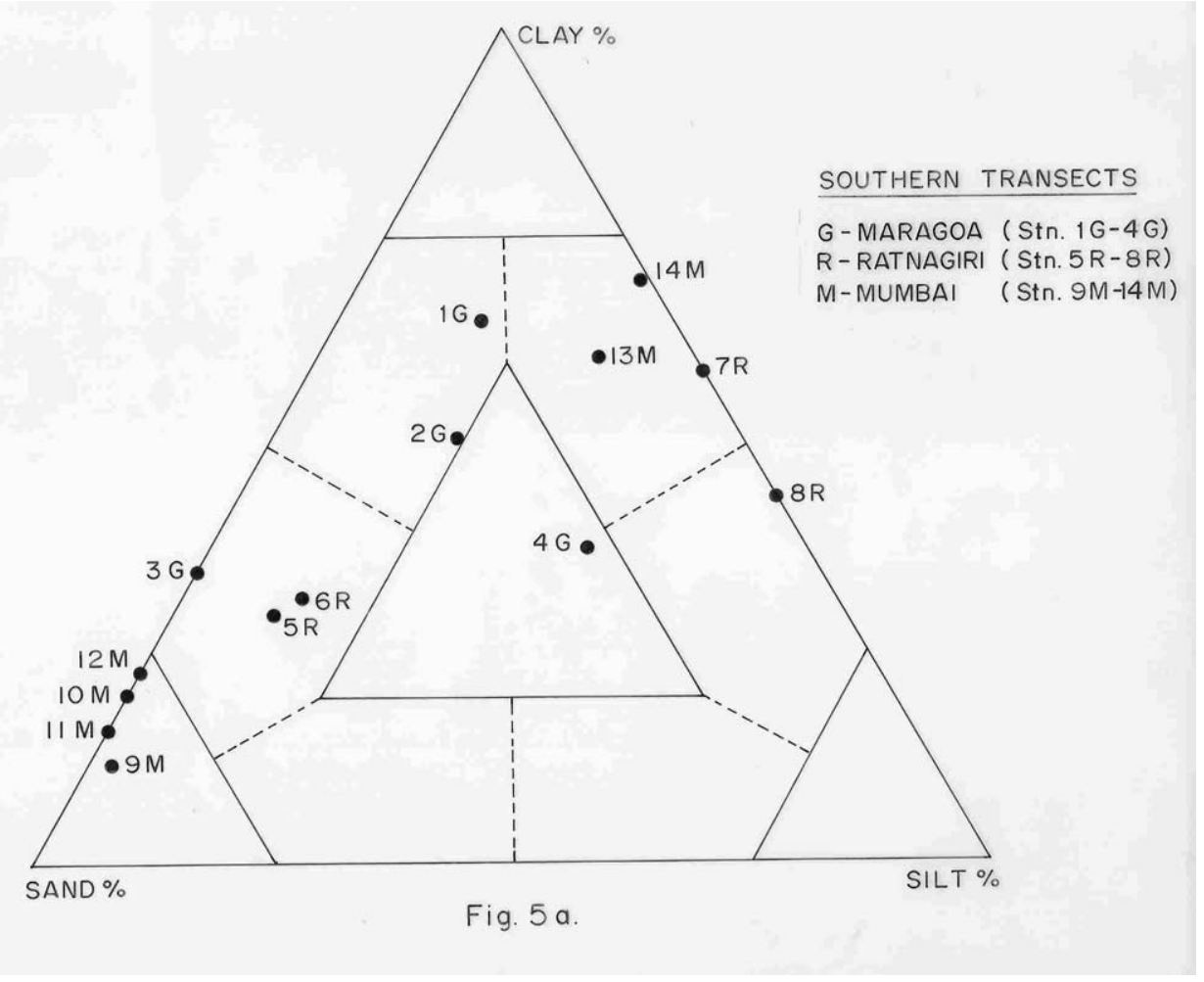

Figure 5 a. 


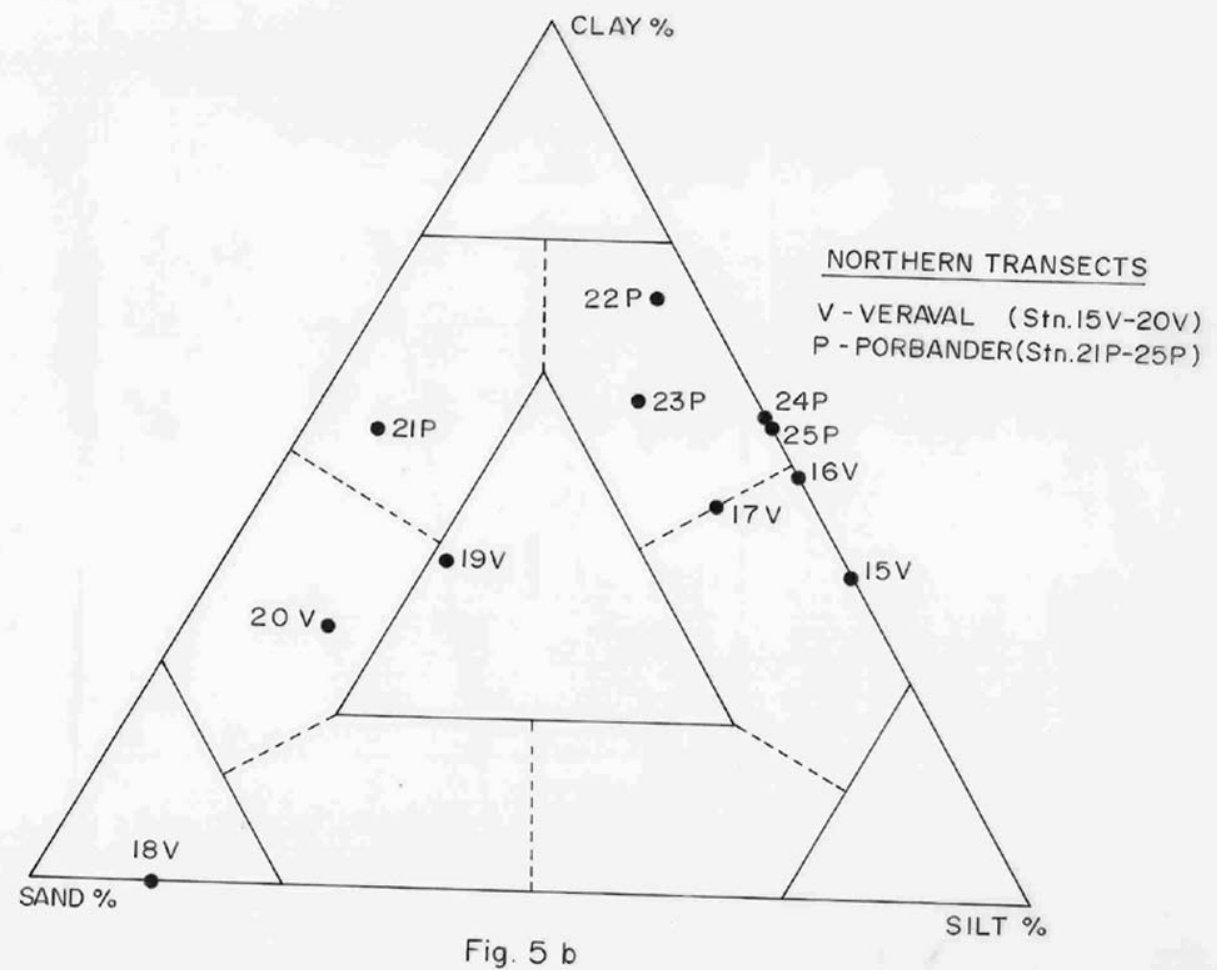

Figure 5 b. 


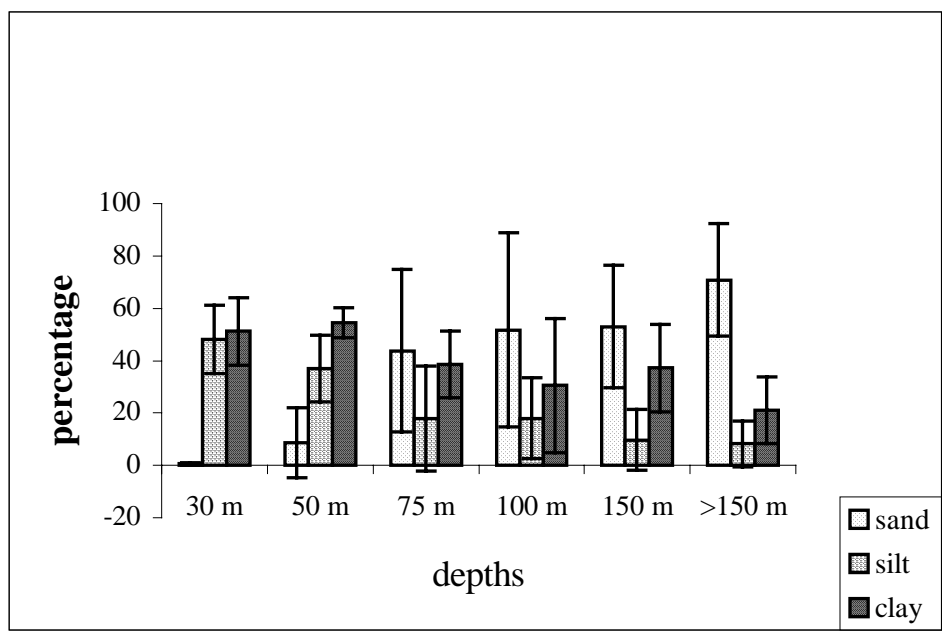

Figure 6.
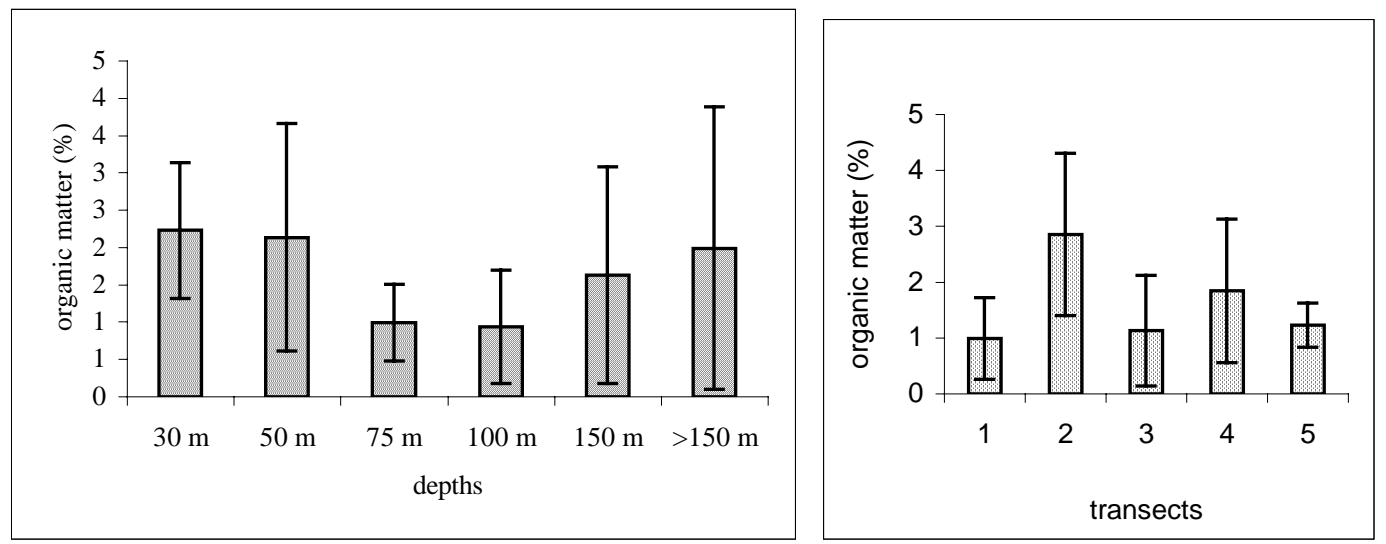

Figure 7a.

Figure 7b. 
a)

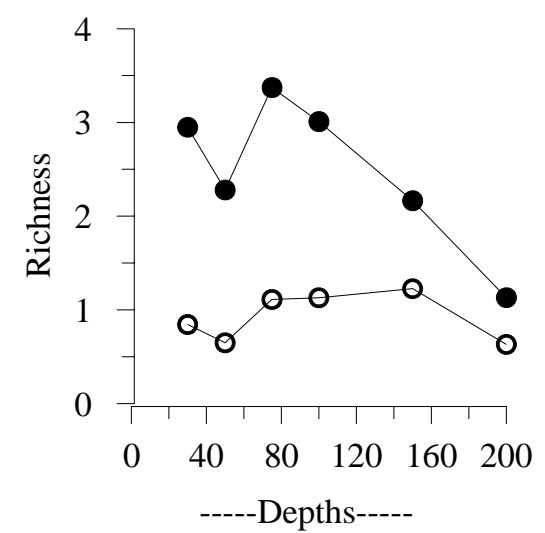

c)

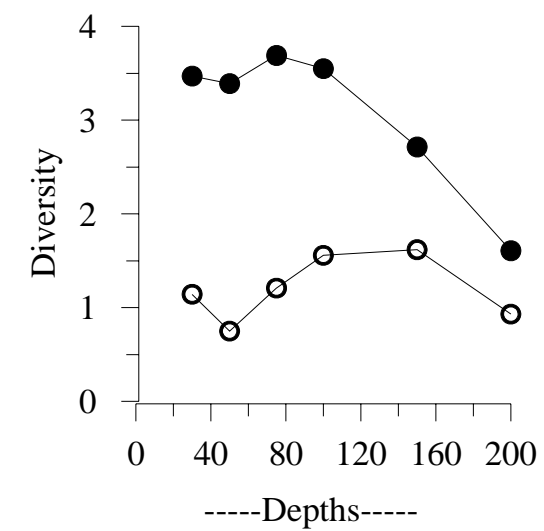

b)

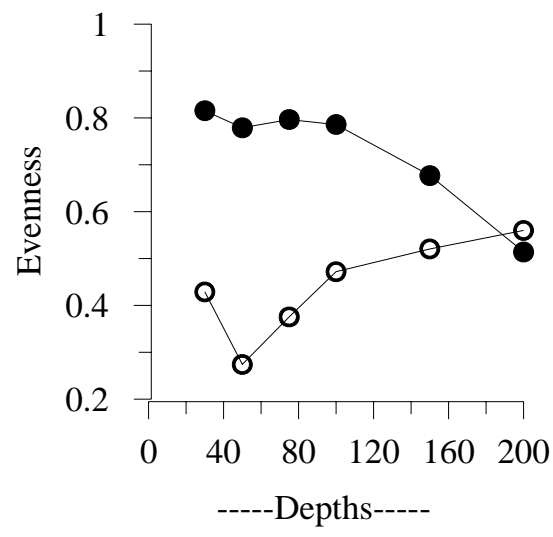

d)

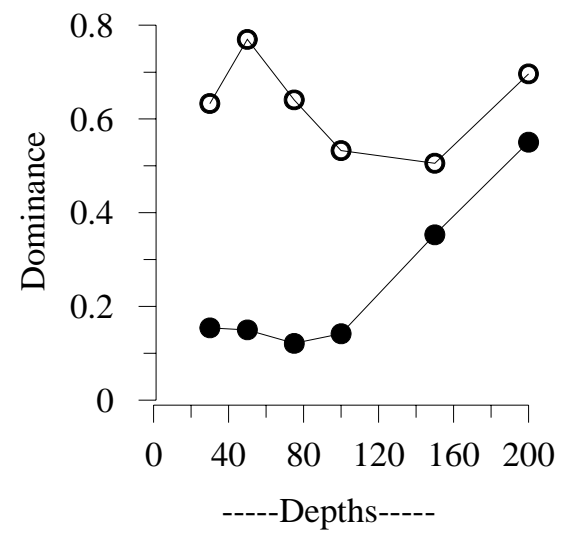

\section{O Polychaete species \\ - whole benthic groups}

Fig. 8 a-d 


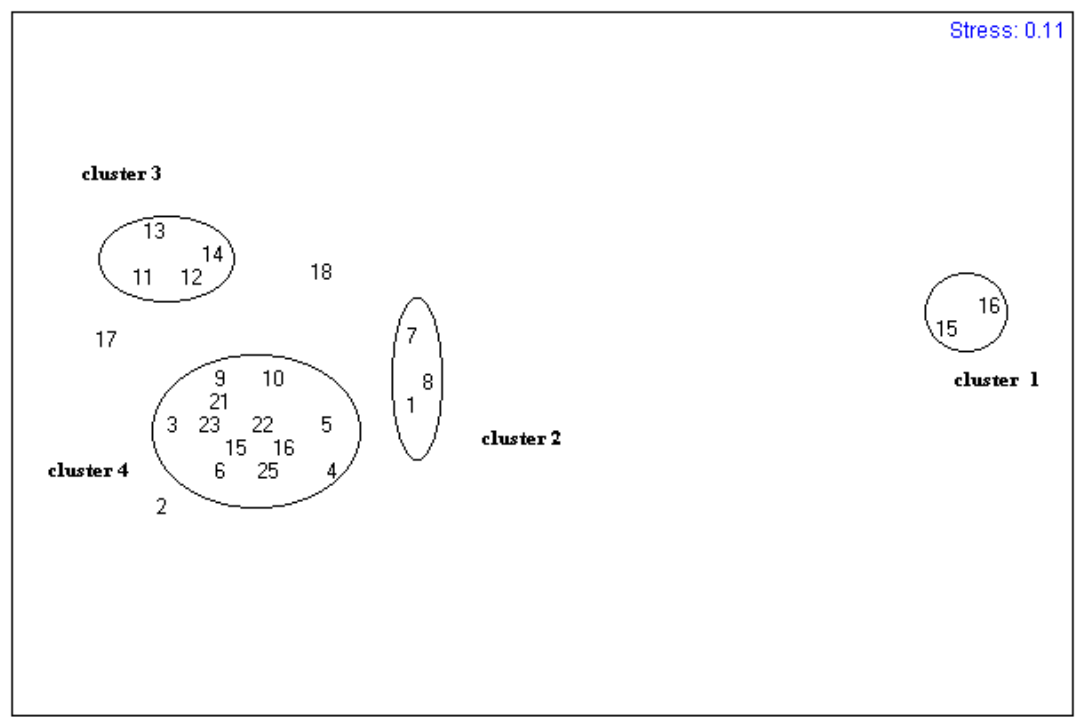

Fig. 9a - Dendrogram (MDS) for stations based on polychaete density

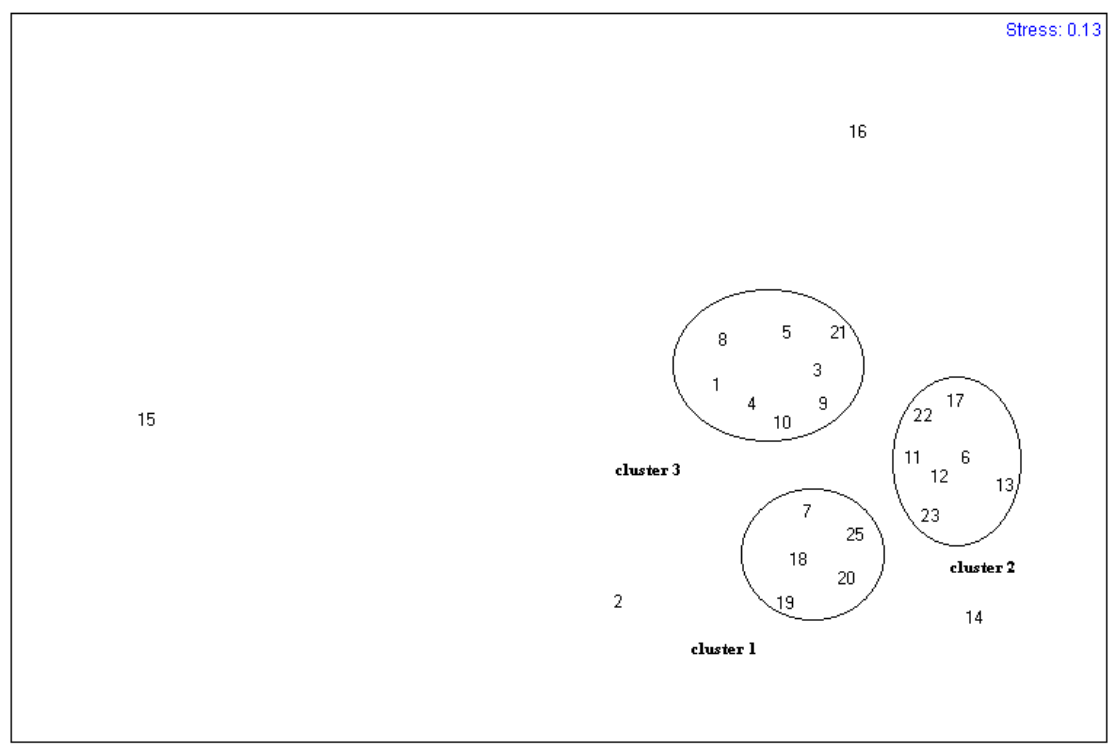

Fig. 9b - Dendrogram (MDS) for stations based on whole benthic group density 